\title{
Productivity and mortality of laying hens in aviaries: a systematic review
}

\author{
V. AERNI ${ }^{*}$, M.W.G. BRINKHOF ${ }^{2}$, B. WECHSLER ${ }^{3}$, H. OESTER ${ }^{4}$ and \\ E. FRÖHLICH ${ }^{4}$
}

${ }^{1}$ Bächlerenweg 20, CH-3044 Säriswil, Switzerland; ${ }^{2}$ Department of Social and Preventive Medicine, Division of Epidemiology and Biostatistics, University of Bern, Finkenhubelweg 11, CH-3012 Bern, Switzerland; 'Swiss Federal Veterinary Office, Centre for Proper Housing of Ruminants and Pigs, CH-8356 Ettenhausen, Switzerland; ${ }^{4}$ Swiss Federal Veterinary Office, Centre for Proper Housing of Poultry and Rabbits, Burgerweg 22, CH-3052 Zollikofen, Switzerland *Corresponding author: vera.aerni@bluewin.ch

\begin{abstract}
A systematic review of investigations on productivity, mortality and cannibalism of laying hens housed in aviaries is presented. In Part One we reviewed the studies that compared these parameters between laying hens housed in aviaries and in conventional cages. In Part Two we investigated the relative impact of strain, beak trimming and rearing condition on productivity and mortality in aviaries. The comparative analysis revealed that aviary hens consumed $3.0 \%$ more food than caged hens, and food conversion was $6.7 \%$ higher in aviaries than in cages. On the other hand, the mortality rate and cannibalism rate did not differ significantly between the two housing systems. The analysis of causes of variation in productivity, mortality rate and cannibalism rate in aviaries revealed a strong effect of strain. Beak trimming was associated with a reduced prevalence of cannibalism rates but had no effect on overall mortality. It also reduced egg weight and food consumption. Early access to litter during the rearing period had a positive effect on egg weight; egg mass, food conversion and mortality rate. In conclusion, we found a slightly reduced productivity of aviaries in relation to cages although the mortality rates and the prevalence of cannibalism did not differ between these housing systems. To further improve productivity and reduce mortality of hens housed in aviaries we recommend the choice of suitable strains and the implementation of improved rearing conditions including early access to litter.
\end{abstract}

Keywords: systematic review; laying hens; aviary; housing system; productivity; mortality; strain; beak trimming; rearing

\section{Introduction}

The aviary housing system for laying hens was developed as an alternative to conventional battery cages. In various countries, this new housing system has been assessed with regard to animal welfare health and economic aspects, and these investigations often compared various parameters between hens housed in aviaries and conventional cages. To draw

(C) World's Poultry Science Association 2005

World's Poultry Science Journal, Vol. 61, March 2005

Received for publication June 4, 2004

130 Accepted for publication December 12, 2004 
general conclusions, however, each of these studies was neither large enough nor covered a sufficiently wide range of conditions. We therefore made a systematic and quantitative review in which we combined the independent results of these studies. The aim of a systematic review is to produce an up-to-date and reproducible account of the present state of research. Moreover, according to Gates (2002), a quantitative review provides a considerable advance in scientific rigour over traditional narrative or "vote-counting" reviews.

An early type of aviary was already operating in 1979 (Fölsch et al., 1983) and since then, the system was further developed. One of the aviary's best features is the construction of tiers and perches above the littered area, which allows the hens to move and get out of the way both horizontally and vertically. Furthermore, the spatial separation of the areas for eating, drinking, resting, foraging and dust bathing is considered as advantageous (Fröhlich, 1995). The use of the third dimension allows for housing additional birds per square metre of ground surface.

In the present systematic review, which is divided in two parts, we investigated the productivity, mortality and cannibalism rates of hens housed in aviaries. The productivity and mortality are important factors for an economical assessment of a laying hen housing system while mortality and cannibalism rates are also used as indicators of animal welfare.

In Part One, we examined the productivity as well as mortality and cannibalism rate of hens housed in aviaries in relation to hens housed in conventional cages by systematically reviewing comparative studies. Generally, the productivity of aviary hens can be as good as that of caged hens (Appleby and Hughes, 1991; Scientific Veterinary Committee, 1996; Tauson, 2002). However, mortality and cannibalism rates of hens housed in aviaries are commonly considered to be higher or more variable than these of hens housed in cages (Bessei, 1997; Bessei and Damme, 1998; Gerken, 1994; Scientific Veterinary Committee, 1996; Tauson, 2002).

In the Part Two we investigated the relative importance of strain, beak condition (trimmed or not trimmed) and rearing condition (access to litter from day one on or from four weeks onwards) on various productivity traits, such as egg weight, egg mass, food consumption and food conversion ratio as well as on mortality and cannibalism rates. To do so, aviary studies were systematically reviewed. All data were analysed using multiple regression models.

\section{Methods}

\section{LOCATION AND SELECTION OF RELEVANT STUDIES}

Publications on productivity and mortality of laying hens kept in aviaries were located by searching the database WEB of Science and by checking the references of the studies retrieved. Only studies published between 1980 and before the end of 2003 were included. In addition, they had to be written in English, German or French.

To minimise bias in the comparison of aviaries and conventional cages (Part One), we only selected studies that used, within-study, the same strain (or strains), hen age classes and beak-trimming methods in both housing systems. All studies included in the comparative analysis are listed in Table 1 . The total number of flocks in aviaries and in cages was 36 and 26 , respectively.

To evaluate causes for variation in laying hen performance in aviaries (Part Two) we extended the data set used for the comparative analysis (Part One) with publications stemming from studies carried out in aviaries only. The analysis was restricted to flocks without access to an outdoor area. In addition, the publications had to provide information on the strains used, the use of beak trimming (yes/no), the rearing condition, the age of the 


\section{Laying hens in aviaries: V. Aerni et al.}

hens when introduced into the laying house and the duration of the investigation. Table 2 presents the aviary studies included. One data set is unpublished (Fröhlich, 2003). The total number of flocks was 124. The data sets used in the analyses of Parts One and Two are available at request from the corresponding author.

\section{DATA}

\section{Data collection}

From the included literature we extracted, where possible, productivity data such as egg weight, egg mass, egg laying rate, food consumption, food conversion ratio as well as figures on mortality and cannibalism. The following five parameters were chosen as predictor variables:

1. Type of housing system, i.e. aviary or conventional cage;

2. Type of strain (genotype, hybrid);

3. Beak trimming (yes or no);

4. Rearing condition with respect to the timing of first access to litter. Since chicks of different studies had access to litter either from day one (early litter) or from four weeks onwards (late litter), rearing condition was classified as a categorical variable with two levels.

5. Age of the hens at the end of the investigation, as calculated from the day of housing and the duration of the investigation period.

Three authors (Kathle and Kolstad, 1996; Leyendecker et al., 2001; Wahlström et al., 1998) were contacted for missing data. The raw data of the study of Wahlström et al. (1998) were not available. Information on other factors that may influence the productivity and mortality of laying hens in aviaries, such as hens per $\mathrm{m}^{2}$ available area, available litter area per hen housed, start of lay, lighting conditions or air quality was often lacking or inadequately documented in the publications. Consequently, these factors were not included in the analyses.

\section{Data management}

Egg mass, egg laying rate and food consumption can be calculated per hen housed or per hen day or per mean hen. These different ways of computation reduced the number of comparable data sets and restricted our analysis to the most often used parameters such as egg mass per hen housed and food consumption per hen day. Egg laying rates were mostly reported without further details, and we therefore analysed this parameter only in Part One, assuming that within study the same method of calculation had been used. We further assumed that the food conversion ratio was calculated either with hen day data or with hen housed data and that means of egg weight were reported.

In the selected studies the data on egg mass, mortality and cannibalism had been collected over dissimilar time periods, varying between 13 and 73 weeks. For statistical comparison, these parameters were standardised to a rate over a period of four weeks (i.e. egg mass/hen housed/four weeks, \% dead hens/hen housed/four weeks and \% dead hens due to cannibalism/hen housed/four weeks).

\section{Data analysis}

The analysis was carried out using the JMP statistical package (Sall et al., 2001). We fitted general linear models to the variation in productivity parameters as well as in mortality and cannibalism rates, and tested the significance of a specified set of predictor variables with F-tests following a stepwise backward procedure (McCullagh and Nelder, 1989). We further tested whether the residuals of each model fitted a normal distribution using the Shapiro-Wilk test. While five productivity parameters, i.e. egg weight, egg mass, 
egg laying rate, food consumption and food conversion, passed the test for normality, mortality rate and cannibalism rate required a log-transformation and a square roottransformation, respectively.

In Part One, which aimed at comparing laying hen performance between aviaries and cages, we fitted multiple regression models with study (as random factor) and housing system (fixed effect, factor with two levels, i.e. aviary and cage) as predictor variables. The inclusion of the factor study statistically controlled for the overall variation in productivity parameters between studies, which may result from a complex variety of sources, including differences in strain use and management procedures. By controlling for such inherent variation between studies, we produced a reasonably unbiased test for the effect of housing system per se. We also tested for significant differences in variance in productivity and mortality parameters between the two housing systems by subjecting the residuals from a statistical model with the factor study only to O'Brien's test of equal variances.

In Part Two, we fitted general linear models to investigate specifically the relative importance of three possible causes for variation in productivity, mortality rate and cannibalism rate in aviaries. These causative factors concerned strain (random factor; 12 levels), beak trimming (fixed effect, two levels: yes or no) and rearing condition (fixed effect, two levels: early litter versus late litter). We further controlled for hen age in all analyses. In addition, the interaction between beak trimming and rearing condition was tested for all parameters. The interaction between strain and beak trimming could only be tested in a subset, which excluded strains with too few data in either beak-trimming class. It was not possible to test the interaction between strain and rearing condition.

\section{Results}

COMPARISON OF PRODUCTIVITY, MORTALITY AND CANNIBALISM BETWEEN AVIARIES AND CAGES

Table 3 summarizes the results of the analysis comparing productivity parameters and mortality between aviaries and cages. Controlling for variation between studies, the housing system had a significant effect on egg mass per hen housed $\left(\mathrm{F}_{1,28}=5.96, \mathrm{P}<0.05\right)$, food consumption $\left(\mathrm{F}_{1,39}=8.48, \mathrm{P}<0.01\right)$ and food conversion $\left(\mathrm{F}_{1,37}=31.89, \mathrm{P}<0.0001\right)$. Aviary hens produced less egg mass and consumed more food than caged hens. Food conversion ratio was higher in aviaries than in cages. Egg weight $\left(\mathrm{F}_{1,33}=0.003, \mathrm{P}=0.95\right)$ and egg laying rate $\left(\mathrm{F}_{1,29}=0.85, \mathrm{P}=0.36\right)$ did not differ between the two housing systems. In addition, neither mortality rate $\left(\mathrm{F}_{1,50}=0.46, \mathrm{P}=0.50\right)$ nor cannibalism rate $\left(\mathrm{F}_{1,30}=0.90\right.$, $\mathrm{P}=0.35$ ) were significantly associated to the housing system. Finally, the variance in food consumption $\left(\mathrm{F}_{1,49}=6.90, \mathrm{P}<0.02\right)$ and in food conversion $\left(\mathrm{F}_{1,47}=6.20, \mathrm{P}<0.02\right)$ was significantly higher in aviaries than in cages. The variance in egg weight $\left(\mathrm{F}_{1,42}=0.00, \mathrm{P}=\right.$ $0.99)$, egg mass $\left(\mathrm{F}_{1,34}=2.69, \mathrm{P}=0.11\right)$, egg laying rate $\left(\mathrm{F}_{1,37}=0.24, \mathrm{P}=0.63\right)$, mortality rate $\left(\mathrm{F}_{1,61}=0.13, \mathrm{P}=0.72\right)$ and cannibalism rate $\left(\mathrm{F}_{1,34}=2.00, \mathrm{P}=0.17\right)$ in aviaries was similar to that in cages (O'Brien's test for equal variances, Table 3).

\section{EFFECTS OF STRAIN, BEAK TRIMMING AND REARING CONDITION ON PRODUCTIVITY PARAMETERS IN AVIARIES}

The results of the analysis of productivity parameters, cannibalism rate and mortality rate in relation to strain, beak trimming, rearing condition and hen age (as controlling factor) are listed in Table 4.

With the exception of egg mass per hen housed $\left(\mathrm{F}_{7,22}=1.59, \mathrm{P}=0.19\right)$, the productivity parameters, i.e. egg weight $\left(\mathrm{F}_{8,22}=2.78, \mathrm{P}<0.05\right)$, food consumption $\left(\mathrm{F}_{9,46}=2.38, \mathrm{P}<\right.$ 


\section{Laying hens in aviaries: V. Aerni et al.}

$0.05)$ and food conversion $\left(\mathrm{F}_{9,28}=3.13, \mathrm{P}<0.01\right)$ significantly differed between strains. Strain differences further accounted for part of the variation in mortality rate $\left(\mathrm{F}_{11.98}=4.51\right.$, $\mathrm{P}<0.0001)$ and in cannibalism rate $\left(\mathrm{F}_{8,44}=6.36, \mathrm{P}<0.0001\right)$.

We further found significant additive effects of beak trimming on egg weight $\left(\mathrm{F}_{1,22}=\right.$ 6.44, $\mathrm{P}<0.05)$, food consumption $\left(\mathrm{F}_{1,46}=30.68, \mathrm{P}<0.0001\right)$ and cannibalism rate $\left(\mathrm{F}_{1,44}=\right.$ $4.21, \mathrm{P}=0.046)$. Untrimmed laying hens produced heavier eggs, consumed more food and had higher cannibalism rates than trimmed hens. Egg mass $\left(\mathrm{F}_{1,21}=0.002, \mathrm{P}=0.97\right)$, food conversion $\left(\mathrm{F}_{1,27}=2.84, \mathrm{P}=0.10\right)$ and mortality rate $\left(\mathrm{F}_{1,97}=0.00, \mathrm{P}=0.99\right)$ were not significantly affected by beak trimming. The rearing condition had an additive effect on the egg weight $\left(\mathrm{F}_{1,22}=5.26, \mathrm{P}<0.05\right)$, egg mass $\left(\mathrm{F}_{1,22}=12.93, \mathrm{P}<0.01\right)$, food conversion $\left(\mathrm{F}_{1,28}=18.06, \mathrm{P}<0.001\right)$ and mortality rate $\left(\mathrm{F}_{1,98}=9.62, \mathrm{P}<0.01\right)$. Hens reared on litter from day one onwards had a higher egg weight and egg mass as well as a lower food conversion and mortality rate than hens deprived of litter for the first four weeks of age. Rearing condition was not significantly associated to food consumption $\left(\mathrm{F}_{1,45}=0.11, \mathrm{P}=\right.$ $0.74)$ and cannibalism rate $\left(F_{1,43}=0.01, P=0.92\right)$. We found no indication for an interaction effect between beak trimming and rearing condition on any of the investigated parameters.

Hen age significantly affected egg weight $\left(\mathrm{F}_{1,22}=13.07, \mathrm{P}<0.01\right)$, mortality rate $\left(\mathrm{F}_{1,98}=\right.$ $4,72, \mathrm{P}<0.05)$ and cannibalism rate $\left(\mathrm{F}_{1,44}=9.72, \mathrm{P}<0.01\right)$, but none of the remaining productivity parameters (Table 4). Older hens had heavier eggs and a higher mortality rate, yet a lower cannibalism rate, than younger hens.

Whether beak trimming had an effect on mortality depending on the strain could only be tested in a subset of the data, which contained the two most common strain types that showed sufficient variation in beak trimming procedure across studies. These hybrids were LSL (no. flocks with - without trimming: 12 - 32) and Hisex White (13 - 6). In the subset, there was a significant interaction effect of strain and beak trimming $\left(\mathrm{F}_{1,54}=8.80\right.$, $\mathrm{P}<0.01$ ) on the mortality rate. A post-hoc Tukey-Kramer HSD (honestly significant difference) test revealed that beak trimming was associated with a higher mortality in the LSL-hybrid, while mortality was essentially unaffected in the Hisex White-hybrid (Figure 1).

\section{Discussion}

In Part One, studies that compared productivity as well as mortality and cannibalism rates between aviaries and conventional cages were systematically reviewed. Strain, beak condition and hen age classes were matched in the two systems and within the studies. We further presumed that researchers took care to equal their trials across the two housing systems as good as possible. Therefore, and by taking the variation between studies into account in the analysis, we believe that the results of the comparison between the two housing systems are convincingly unbiased.

We found that aviary hens consumed more food and produced less egg mass per hen housed. The food conversion ratio, as a result, was poorer in aviaries than in cages. It has been supposed that aviary hens consume more food because they need extra energy for maintenance at low ambient temperature or when feather cover is poor (Scientific Veterinary Committee, 1996) or for more locomotor activity (Tauson, 2002; van Niekerk and Ehlhardt, 1995). Alternatively, differences in food consumption may be due to differences in food intake or food wastage. Unfortunately, it was not reported in the reviewed studies whether or not the method of measuring food consumption took losses of food into account. The difference in egg mass is probably due to higher chance of egg losses in aviaries than in cages (Appleby and Hughes, 1991; Scientific Veterinary 
Committee, 1996). The variation in food consumption and food conversion revealed to be higher in aviaries than in cages. A possible explanation could be found in the fact that different types of aviaries were used within study. Egg weight and egg laying rate did not significantly differ between systems.

By combining and quantitatively analysing data on mortality and cannibalism rates from the selected studies, we found no differences in the mean values or in variances between aviaries and cages. Thus, we found no support for the supposition of several authors (Bessei, 1997; Bessei and Damme, 1998; Gerken, 1994; Scientific Veterinary Committee, 1996; Tauson, 2002), that mortality and cannibalism rates tend to be higher in aviaries than in cages. Lower mortality rates in aviaries than in cages were reported in a cross-sectional, epidemiological investigation (van Horne, 1996; van Horne et al., 1997). This result, however, could have been biased by confounding factors. For example strains were not evenly distributed between the two housing systems.

The analysis of the comparative investigations further revealed considerable differences among studies regarding mortality and cannibalism rates as well as most productivity traits. This points out the strong influence of confounders, i.e. factors other than the housing system, affecting productivity and mortality. Rushen (2003) stressed the importance of recognising the effect of such confounding factors when assessing housing systems.

In Part Two, we investigated the impact of strain, beak condition and rearing condition on productivity as well as mortality and cannibalism rates of hens housed in aviaries. Strain was found to have an influence on the egg weight, the food consumption and the food conversion ratio. The strain further seemed to be an important factor affecting variation in mortality and cannibalism rates of hens housed in aviaries. A relation between strain and mortality of hens housed in alternative systems was also found in the epidemiological study of Häne (1999). Kjaer and Sørensen (2002) experimentally investigated, among other factors, the effect of genotype on feather pecking and cannibalism of hens housed in small-scale free-range systems. They found significant differences in mortality due to cannibalism between genotypes. Thus, to reduce mortality and improve productivity of laying hens kept in aviaries, it is crucial to choose suitable strains.

In their review Hughes and Gentle (1995) concluded that beak trimming has an economic advantage for the producer, because it would reduce mortality by inhibiting cannibalism. They also supposed that beak trimmed laying hens eat slightly less food and have a slightly improved food conversion ratio than untrimmed birds. In accordance to this, we found that trimmed hens consumed $7.5 \%$ less food than untrimmed hens. However, and in contrast to Hughes and Gentle (1995) there was no association of beak trimming and the food conversion ratio. Given these results, one would expect a higher egg mass production in untrimmed hens, yet we did not find a relation between beak trimming and egg mass.

In line with Hughes and Gentle (1995), we found a lower prevalence of cannibalism in trimmed hens, the difference was just significant. On the other hand and consistent with the findings of Häne (1999), total mortality rate was not related to beak trimming. Thus, the effect of beak trimming on cannibalism was not reflected in the mortality rate suggesting a compensative effect. Such a compensative effect was found in a subgroup analysis testing the interaction of beak and strain on mortality. This interaction revealed to be significant and, as shown in Figure 1, the influence of beak trimming depends on the strain used. Interestingly, we found that beak trimming may even have a negative effect on mortality in laying hens. However, we are aware that such subgroup analyses have to be interpreted cautiously and that further investigations are needed.

Rearing the hens with early access to litter was associated with a positive effect on egg 


\section{Laying hens in aviaries: V. Aerni et al.}

production as well as on the incidence of mortality. Hens reared on litter from day one on produced heavier eggs and a higher egg mass. Furthermore, they had a lower food conversion and a lower mortality rate than hens having access to litter but from four weeks onwards.

An influence of early access to litter on productivity as well as mortality has also been reported by Johnsen et al. (1998). In their experimental study, hens reared on wire for the first four weeks of life had a lower egg production and a higher total mortality rate than hens reared on sand or straw from day one on. Gunnarsson et al. (1999) investigated the effect of rearing conditions on behavioural problems in a cohort study of 59 flocks kept in aviaries. In line with our results, they did not find an association of early access to litter and the incidence of cannibalism. Thus, the reducing effect of early access to litter on mortality is likely to be due to factors other than cannibalism.

We selected the factors strain, beak trimming and rearing condition because they were described in the investigations and, furthermore, their influence on productivity and mortality was shown before in single experimental investigations. We implicitly assumed that the results of our study are not confounded by factors such as housing density, start of lay, lighting conditions or air quality, which were incompletely and inadequately reported in the reviewed studies.

To improve the quality of reporting, we suggest that in the field of poultry research reporting guidelines should be adopted. Enhanced reporting of observational studies will facilitate critical appraisal and promote the adequate use of research evidence.

\section{Conclusions}

Performance regarding food consumption and food conversion seems to be slightly poorer in hens housed in aviaries than in hens housed in cages. To identify the causes of these differences, studies measuring both real food intake and food wastage are needed. Since food consumption and food conversion ratio (Abrahamsson and Tauson, 1995; Kathle and Kolstad, 1996) as well as food wastage (Meierhans, 1993) vary considerably between different types of aviaries, it may be possible to improve productivity through technical perfection of this housing system. In contrast to conclusions based on the results of single investigations or narrative reviews, our quantitative review showed that the mortality rate, the variance in mortality as well as the prevalence of cannibalism do not seem to be associated to the housing system. To improve productivity and reduce mortality of hens housed in aviaries, the choice of suitable strains and the implementation of enhanced rearing conditions are likely to be essential. It is therefore recommended to rear laying hens with access to litter from day one on. Besides the positive effect on productivity and mortality, this rearing condition also reduces the prevalence of feather pecking, as shown by Blokhuis (1998), Gunnarsson et al. (1999), Huber-Eicher and Sebö (2001) and Johnsen et al. (1998).

\section{Acknowledgements}

We are grateful to the Felix-Wankel foundation for financial support. 


\section{References}

ABRAHAMSSON, P. and TAUSON, R. (1995) Aviary systems and conventional cages for laying hens: effects on production, egg quality, health and bird location in three hybrids. Acta Agriculturae Scandinavica, Section A, Animal Science 45: 191-203.

ABRAHAMSSON, P., FOSSUM, O. and TAUSON, R. (1998) Health of laying hens in an aviary system over fives batches of birds. Acta Veterinaria Scandinavica 39: 367-379.

AMGARTEN, M. and MEIERHANS, D. (1992) Vergleichende Untersuchungen der Wirtschaftlichkeit verschiedener Haltungssysteme für Legehennen in der Praxis und an der SGS. Swiss Poultry Husbandry School, Zollikofen, Switzerland.

APPLEBY, M.C. and HUGHES, B.O. (1991) Welfare of laying hens in cages and alternative systems: environmental, physical and behavioural aspects. World's Poultry Science Journal 47: 109-128.

BESSEI, W. (1997) The behaviour of laying hens in aviary systems (a literature review). Archiv für Geflügelkunde 61: 176-180.

BESSEI, W. and DAMME, K. (1998) Neue Verfahren für die Legehennenhaltung. Kuratorium für Technik und Bauwesen in der Landwirtschaft e.V. (KTBL), Darmstadt, Germany.

BLOKHUIS, H.J. and WIEPKEMA, P.R. (1998) Studies of feather pecking in poultry. The Veterinary Quarterly 20: 6-9.

BOSCH, J.G.M.J. and VAN NIEKERK, T.G.C.M. (1995) Aviary housing for laying hens: Health. ID-DLO Institute for Animal Science and Health, Lelystad, The Netherlands.

EHLHARDT, D.A., DONKERS, A.M.J. and GERRITSEN, C.L.M. (1988) Alternative improved housing systems for poultry. Commission of the European Communities, Brussels, Luxembourg.

ENGSTRÖM, B. and SCHALLER, G. (1993) Experimental studies of the health of laying hens in relation to housing system In: Proceedings of Fourth European Symposium on Poultry Welfare, Edinburgh, pp. 87-96.

FÖLSCH, D.W., RIST, M., MUNZ, G. and TEYGELER, H. (1983) Entwicklung eines tiergerechten Legehennen-Haltungssystems: Die Volierenhaltung. Landtechnik: 255-257.

FRÖHLICH, E. (1995) Erfahrungen mit der Volierenhaltung von Legehennen sowie anderen Alternativen In: Proceedings of Tagung der Deutschen Veterinärmedizinischen Gesellschaft, Fachgruppe "Tierschutzrecht und Gerichtliche Veterinärmedizin”, Stuttgart-Hohenheim, pp. 111-130.

FRÖHLICH, E. (2003) Mortalität in verschiedenen Aufstallungssystemen der praktischen Prüfung 1984-1996. Internal report. Federal Veterinary Office, Centre for Proper Housing: Poultry and Rabbits, Zollikofen, Switzerland.

GATES, S. (2002) Review of methodology of quantitative reviews using meta-analysis in ecology. Journal of Animal Ecology 71: 547-557.

GERKEN, M. (1994) Bewertung von alternativen Haltungssystemen für Legehennen. Archiv für Geflügelkunde 58: 206-213.

GROOT-KOERKAMP, P.W.G., KEEN, A., VAN NIEKERK, T.G.C.M. and SMIT, S. (1995) The effect of manure and litter handling and indoor climatic conditions on ammonia emissions from a battery cage and an aviary housing system for laying hens. Netherlands Journal of Agricultural Science 43: 351-373.

GUNNARSSON, S., KEELING, L.J. and SVEDBERG, J. (1999) Effect of rearing factors on the prevalence of floor eggs, cloacal cannibalism and feather pecking in commercial flocks of loose housed laying hens. British Poultry Science 40: 12-18.

GUNNARSSON, S., ODÉN, K., ALGERS, B., SVEDBERG, J. and KEELING, L.J. (1995) Poultry health and behaviour in a tiered system for loose housed layers. Swedish University of Agricultural Sciences. Department of Animal Hygiene, Skara, Sweden.

HÄNE, M. (1999) Legehennenhaltung in der Schweiz 1998. Federal Veterinary Office, Centre for Proper Housing: Poultry and Rabbits, Zollikofen, Switzerland.

HILL, J.A. (1981) The aviary system In: Proceedings of First European Symposium on Poultry Welfare, Kopenhagen, pp. 115-123.

HUBER-EICHER, B. and SEBÖ, F. (2001) Reducing feather pecking when raising laying hen chicks in aviary systems. Applied Animal Behaviour Science 73: 59-68.

HUGHES, B.O. and GENTLE, M.J. (1995) Beak trimming of poultry: its implications for welfare. World's Poultry Science Journal 51: 51-61.

JOHNSEN, P.F., VESTERGAARD, K.S. and NØRGAARD-NIELSEN, G. (1998) Influence of early rearing conditions on the development of feather pecking and cannibalism in domestic fowl. Applied Animal Behaviour Science 60: 25-41.

KATHLE, J. and KOLSTAD, N. (1996) Non-beaked laying hens housed in aviaries 1: production performance in cages and three types of aviaries. Norwegian Journal of Agricultural Sciences 10: 413-424.

KJAER, J.B. and SøRENSEN, P. (2002) Feather pecking and cannibalism in free-range laying hens as affected by genotype, dietary level of methionin + cystine, light intensity during rearing and age at first access to the range area. Applied Animal Behaviour Science 76: 21-39. 
Laying hens in aviaries: V. Aerni et al.

LANGE, K. (1997) Leistungsverhalten verschiedener Hybridherkünfte im Vergleich der Käfig- zur Volierenhaltung. In: Petersen, J. (Ed.) Jahrbuch für Geflügelwirtschaft 1997, Verlag Eugen Ulmer, Stuttgart, Germany, pp. 45-49.

LEYENDECKER, M., HAMANN, H., HARTUNG, J., KAMPHUES, J., RING, C., GLUNDER, G., AHLERS, C., SANDER, I., NEUMANN, U. and DISTL, O. (2001) Analysis of genotype-environment interactions between layer lines and housing systems for performance traits, egg quality and bone breaking strength. 1st communication: performance traits. Züchtungskunde 73: 290-307.

McCULLAGH, P. and NELDER, J.A. (1989) Generalised linear models. Chapman and Hall, London.

MEIERHANS, D. (1993) Vergleichsversuch neuer Haltungssysteme für Legehennen. No 12. Swiss Poultry Husbandry School, Zollikofen, Switzerland.

MICHEL, V. and HUONNIC, D. (2003) A comparison of welfare, health and production performance of laying hens reared in cages or in aviaries. British Poultry Science 44: 775-776.

RUSHEN, J. (2003) Changing concepts of farm animal welfare: bridging the gap between applied and basic research. Applied Animal Behaviour Science 81: 199-214.

SALL, J., LEHMANN, A. and CREIGHTON, L. (2001) JMP start statistics. A guide to statistics and data analysis. SAS Institute Inc. / Duxbury, Pacific Grove, CA.

SCIENTIFIC VETERINARY COMMITTEE (1996) Report on the welfare of laying hens. Commission of the European Communities, Directorate-General for Agriculture, Brussels, Luxembourg.

TANAKA, T. and HURNIK, J.F. (1992) Comparison of behavior and performance of laying hens housed in battery cages and an aviary. Poultry Science 71: 235-243.

TAUSON, R. (2002) Furnished cages and aviaries: production and health. World's Poultry Science Journal 58 49-63.

TAUSON, R. and JANSSON, L. (1990) Two alternative keeping systems for egg laying hens in comparison with furnished cages In: Proceedings of 8th European Poultry Conference, Barcelona, pp. 676-679.

TAUSON, R., WAHLSTRÖM, A. and ABRAHAMSSON, P. (1999) Effect of two floor housing systems and cages on health, production, and fear response in layers. Journal of Applied Poultry Research 8: 152-159.

VAN HORNE, P.L.M. (1996) Production and economic results of commercial flocks with white layers in aviary systems and battery cages. British Poultry Science 37: 255-261.

VAN HORNE, P.L.M., VAN NIEKERK, T.G.C.M. and BOSCH, J.G.M.J. (1997) Production, animal health and economic results of commercial layer flocks in aviary systems In: Proceedings of 9th International Congress in Animal Hygiene, Helsinki, Finland, pp. 561-564.

VAN NIEKERK, T.G.C.M. and EHLHARDT, D.A. (1995) Aviary housing for laying hens: Zootechnics. IDDLO Institute for Animal Science and Health, Lelystad, The Netherlands.

WAHLSTRÖM, A., TAUSON, R. and ELWINGER, K. (1998) Effects on plumage condition, health and mortality of dietary oats/wheat ratios to three hybirds of laying hens in different housing systems. Acta Agriculturae candinavica Section A-Animal Science 48: 250-259.

WAHLSTRÖM, A., TAUSON, R. and ELWINGER, K. (2001) Plumage condition and health of aviary-kept hens fed mash or crumbled pellets. Poultry Science 80: 266-271. 
Laying hens in aviaries: V. Aerni et al.

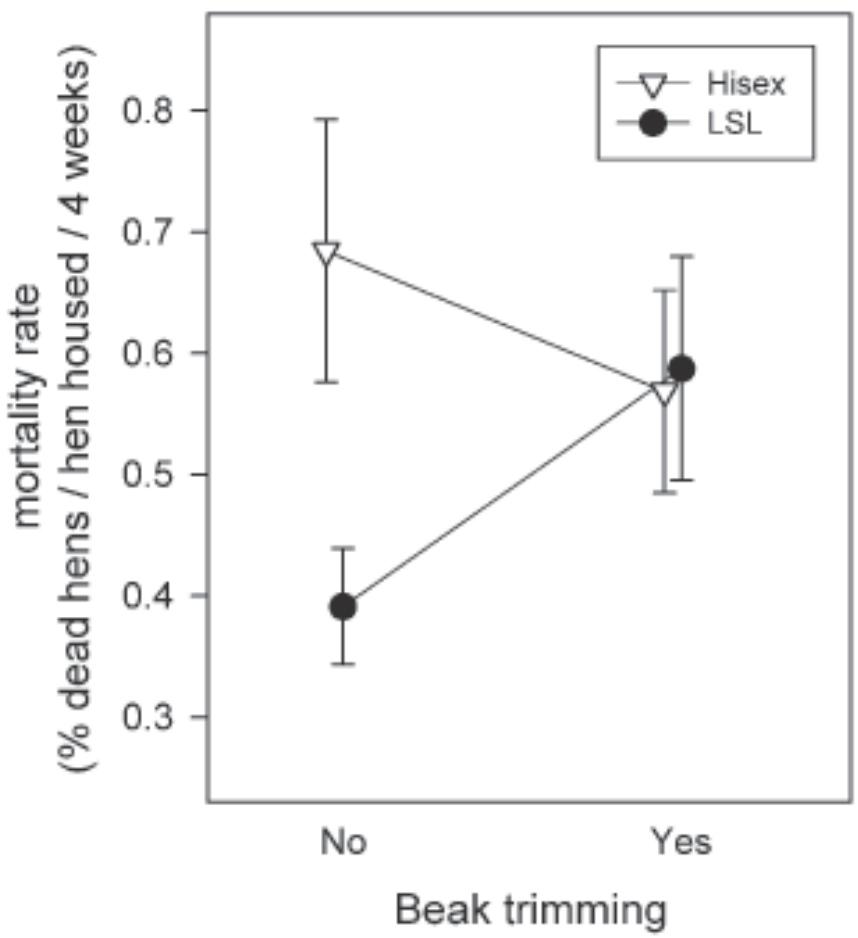

Figure 1 Strain-specific variation in the effect of beak trimming on mortality. 
Laying hens in aviaries: V. Aerni et al.

Table 1 Publications included in the comparison of laying hen productivity and mortality in aviaries and cages (Part One).

\begin{tabular}{|c|c|c|c|c|}
\hline \multirow[b]{2}{*}{ Author } & \multirow[b]{2}{*}{ Strain } & \multicolumn{2}{|c|}{ N flocks } & \multirow[b]{2}{*}{ Remark } \\
\hline & & Aviary & Cages & \\
\hline Abrahamsson and Tauson (1995) & LSL & 4 & 2 & \multirow{6}{*}{$\begin{array}{l}\text { Mortality and } \\
\text { cannibalism data }\end{array}$} \\
\hline \multirow{3}{*}{ Bosch and van Niekerk (1995) ${ }^{1}$} & LSL & 2 & 2 & \\
\hline & Hisex & 2 & 1 & \\
\hline & Isa & 1 & 1 & \\
\hline \multirow{2}{*}{ Ehlhardt et al. (1988) } & LSL & 1 & 1 & \\
\hline & Isa & 1 & 1 & \\
\hline Engström and Schaller (1993) ${ }^{2}$ & Norbrid & 9 & 3 & \multirow{2}{*}{$\begin{array}{l}\text { Mortality and cannibalism } \\
\text { data from Norwegian trial }\end{array}$} \\
\hline \multirow{2}{*}{ Groot-Koerkamp et al. (1995) } & LSL & 1 & 1 & \\
\hline & Isa & 1 & 1 & \multirow{8}{*}{ Productivity data } \\
\hline \multirow[t]{2}{*}{ Hill (1981) } & Shaver & 1 & 1 & \\
\hline & Warren & 1 & 1 & \\
\hline Kathle and Kolstad (1996) ${ }^{2}$ & Norbrid & 9 & 3 & \\
\hline \multirow{4}{*}{ Lange (1997) } & LSL & 1 & 1 & \\
\hline & Hisex & 1 & 1 & \\
\hline & Isa & 1 & 1 & \\
\hline & Lohmann $^{3}$ & 1 & 1 & \\
\hline \multirow[t]{2}{*}{ Leyendecker et al. (2001) } & LSL & 1 & 1 & \\
\hline & Lohmann $^{4}$ & 1 & 1 & \\
\hline Michel and Huonnic (2003) & n.m. ${ }^{5}$ & 1 & 1 & \\
\hline Tanaka and Hurnik (1992) & Dekalb & 1 & 1 & \\
\hline Tauson and Jansson (1990) & LSL & 2 & 1 & \\
\hline \multirow[t]{2}{*}{ Tauson et al. (1999) } & LSL & 1 & 1 & \multirow{5}{*}{ Productivity data } \\
\hline & Lohmann $^{3}$ & 1 & 1 & \\
\hline \multirow{3}{*}{ van Niekerk and Ehlhardt (1995) ${ }^{1}$} & LSL & 2 & 2 & \\
\hline & Hisex & 2 & 1 & \\
\hline & Isa & 1 & 1 & \\
\hline
\end{tabular}

1,2 same superscript indicates same investigation

${ }^{3}$ Lohmann brown

${ }^{4}$ Lohmann tradition

${ }^{5}$ not mentioned

Table 2 Studies included in the analyses to investigate causes of variation in productivity, mortality and cannibalism in aviaries (Part Two).

\begin{tabular}{llll}
\hline Study & $\mathbf{N}^{\mathbf{1}}$ & Beak trimmed $^{\mathbf{2}}$ & Rearing condition $^{\mathbf{3}}$ \\
\hline Abrahamsson and Tauson (1995) & 7 & no & LL \\
Abrahamsson et al. (1998) & 20 & no & 4 EL, 16 LL \\
Amgarten and Meierhans (1992) & 19 & 17 yes, 2 no & EL \\
Ehlhardt et al. (1988) & 2 & yes & EL \\
Engström and Schaller (1993) & 9 & no & EL \\
Fröhlich (2003) & 30 & no yes, 14 no & EL \\
Gunnarsson et al. (1995) & 2 & no & 1 EL, LL \\
Kathle and Kolstad (1996) & 9 & no & EL \\
Lange (1997) & 4 & yes, 1no & EL \\
Leyendecker et al. $(2001)$ & 2 & no & EL \\
Meierhans (1993) & 2 & no & EL \\
Tanaka and Hurnik (1992) & 1 & no & LL \\
Tauson and Jansson (1990) & 2 & yes & LL \\
Tauson, et al., (1999) & 2 & no & LL EL, 1LL \\
van Niekerk and Ehlhardt (1995) & 11 & & LL \\
Wahlström et al. (2001) & 2 & &
\end{tabular}

${ }^{1} \mathrm{~N}=$ number of flocks

${ }^{2}$ Beak trimmed $=$ yes, untrimmed $=$ no

${ }^{3}$ Rearing with access to litter from day one $=\mathrm{EL}$, from four weeks onwards $=\mathrm{LL}$ 
Laying hens in aviaries: V. Aerni et al.

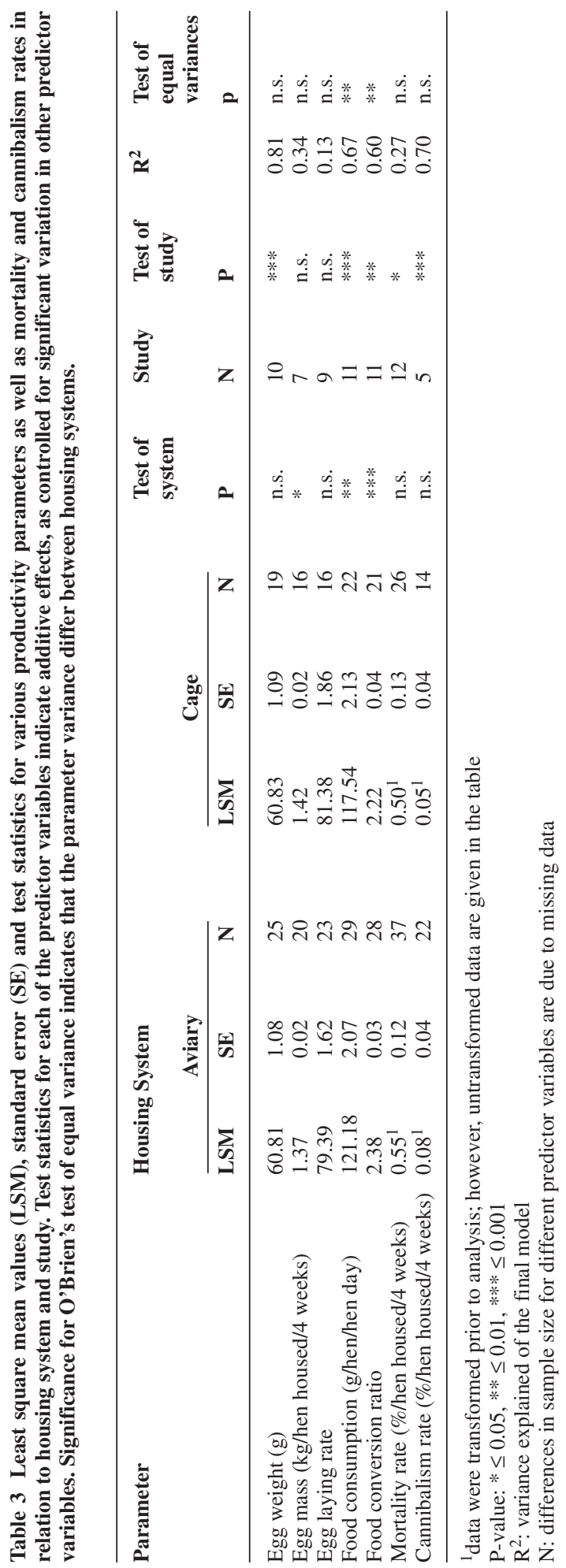

World's Poultry Science Journal, Vol. 61, March 2005 
Laying hens in aviaries: V. Aerni et al.

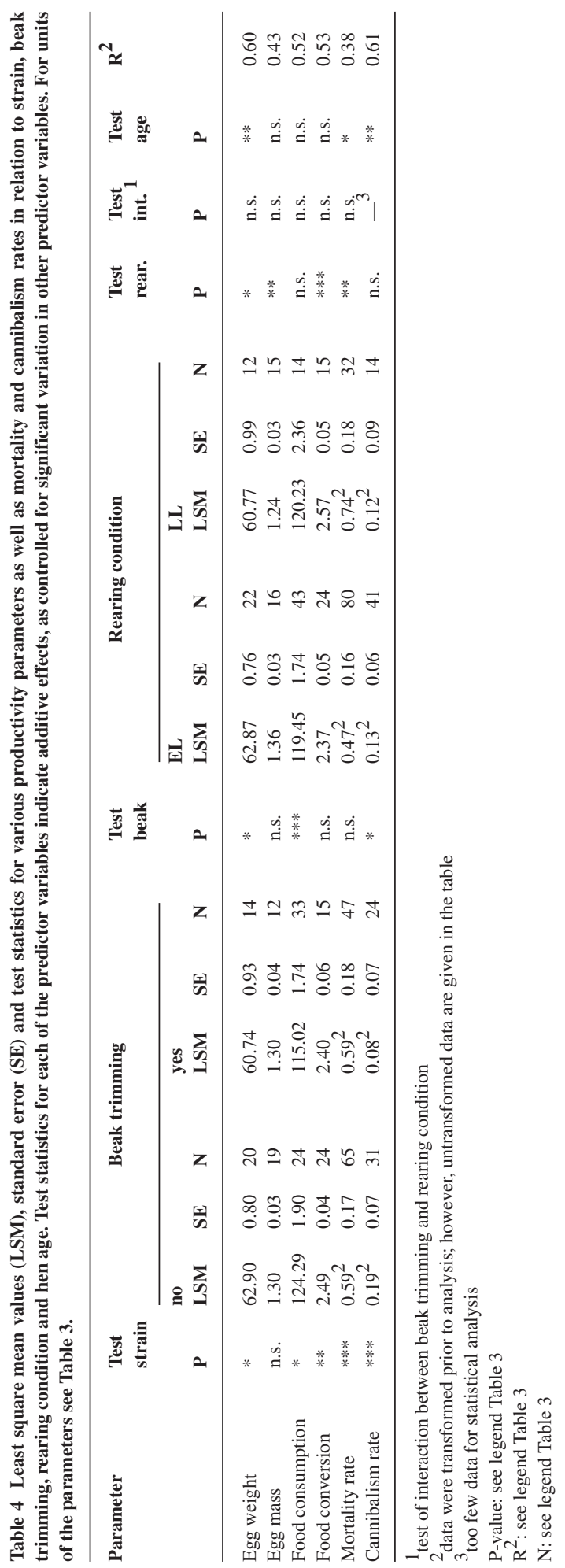

142 World's Poultry Science Journal, Vol. 61, March 2005

Downloaded from https:/www.cambridge.org/core. University of Basel Library, on 30 May 2017 at 21:00:13, subject to the Cambridge Core terms of use, available at https:/www.cambridge.org/core/terms. https://doi.org/10.1079/WPS200450 